\title{
Mapping and Analysing \\ Environmental Noise Using \\ Smartphones in Small Towns - A \\ Hungarian Case Study
}

Gl_Forum 2017, Issue 2

Page: 126 - 136

Full Paper

Corresponding Author:

podor.andrea@amk.uni-obuda.hu

DOI: 10.1553/giscience2017_02_s126

\author{
Andrea Pődörl and András Révész ${ }^{2}$ \\ 'Óbuda University Székesfehérvár, Hungary \\ 2Barnsley Council, UK
}

\begin{abstract}
The study summarizes 3 years' experience in mapping and analysing environmental noise using smartphones. The authors used participatory noise mapping utilizing smartphonebased measurement data. The data were visualized on maps and the results were investigated. The maps confirm that data from participatory measurements can reveal environmental noise exposure. The findings could be used as a starting point for local governments to finance official noise measurements.
\end{abstract}

\section{Keywords:}

noise mapping, smartphone noise measurement, participatory noise measurement

\section{Introduction}

Noise pollution is one of the main (and growing) environmental problems in urban areas. According to the Environmental Noise Directive of the European Union 2002/49/EG article 7 , agglomerations with a population of more than 250,000 should create a local noise map. In Hungary, the Hungarian Government Decree 280/2004 (X.20) was implemented in 2004 to comply with the Directive. Since the only city in Hungary with a population of more than 250,000 is the capital, the Hungarian Decree requires towns and cities of more than 100,000 to comply with the Directive. The Decree also requires renewing these maps every five years. However, due to the lack of financial resources local authorities are unable to fund the renewal of these maps. Environmental noise pollution is also interesting for towns with smaller populations.

We investigated whether crowdsourced data collection is a viable option for updating and creating noise maps. Thanks to the increased availability of location-enabled smartphones with a range of digital sensors including sound recorders, this kind of data acquisition may be promising (Pődör \& Révész, 2014, Pődör et al., 2015). Because different mobile applications produce different outputs, user-generated noise measurements cannot replace professional 
surveys, but they can provide additional data for strategic noise mapping and monitoring (Pődör \& Révész, 2014).

Various studies have compared maps generated from professional and from user-generated measurements. Garcia-Marti et al (2014) used VGI (Volunteered Geographic Information) measurements from 9 types of mobile device. All measurements were collected at the Campus of University Jaume I (Spain). The authors found that maps generated by combining VGI data from multiple mobile sources are more similar to maps derived from professional data than maps generated from the data of a particular mobile device. Garcia-Marti et al used the NoiseBattle software.

In another paper, Marti et al (2012) compared official noise measurements and VGI measurements, analysing the raster surfaces generated by each set of measurements. The problem with this comparison is that the data for the official measurements were presented as a grid, while the VGI data did not follow any pattern. Furthermore, the two sets of data were acquired on different dates, so it was not possible to extract exact information about the accuracy of the measurements.

Using crowdsourced noise measurements has been investigated extensively, and several applications have been developed, such as NoiseTube (Maisonneuve et al., 2009) and NoiseSpy (Kanjo, 2010).

Santini et al (2009) also tested a number of mobile devices versus a phonometer. They tried 2 applications, a Java- and a Python-based one, and found that the Java-based application worked better. They also found that the noise levels measured by mobile phones may differ from the results of a sound-level meter. Karolus (2013) and Kanjo (2010), on the other hand, found that smartphones using adequate software are capable of measuring noise exposure.

Miller et al (2016) investigated the ways in which measurements made using smartphone applications can be integrated in a strategic noise mapping process, examining the use of smartphones for an assessment of environmental noise. They developed a noise map using smartphone data and compared this to a noise map produced using traditional methodologies. They found the greatest differences near the busiest road segments. They also stated that a noise map based on smartphone measurements might be more representative of the actual acoustic environment.

All these studies are very interesting and promising, but none uses mobile phones for mapping the noise exposure of a whole area. Our approach was to make a noise exposure map of an entire town or other area of interest using data collected on the same day (if possible once during rush hour, and once during off-peak hours). The aim of our study was to investigate whether a smartphone would be able to detect noisy and quiet places in a municipality as a whole. Therefore, we planned 2 measurement campaigns, in 2015 and in 2016. We prepared noise exposure maps for 11 entire municipalities, one mine and one racetrack, also creating maps of some parts of Székesfehérvár. Our hypothesis was that main roads and junctions would be the noisiest areas, and parks and residential quarters the quietest areas. We investigated whether our results would be confirmed by the crowdsourced noise measurements. 


\section{Study areas}

With the help of students studying at Óbuda University, we investigated towns with fewer than 100,000 inhabitants, because they are not obliged to make an official noise map. They therefore have limited options to secure funding, even if they consider noise pollution to be an important issue. The towns investigated ranged from approximately 2,000 to 90,000 people (Hungarian Central Statistical Office, 2015): Ajka (28,487), Beled (2,640), Cserkeszőlő (2,218), Dunaföldvár (8,593), Gyula (30,658), Kapuvár (103,93), Nagykanizsa (48,241), Nagykőrös $(23,694)$, Sopron $(61,780)$, Zalaegerszeg $(58,959)$, Székesfehérvár $(98,673)$.

We also made experiments at Pannonia Ring, a racetrack near Ostffyasszonyfa, and at a dolomite stone mine near Iszkaszentgyörgy.

\section{Methodology}

The noise measurement campaign started with the designation of the measurement points. We used simple Google maps, with symbols indicating the measurement points. We tried to position points in such a way that they would cover the whole area, form a grid-like layout, and could all be visited within one day on foot or using a bicycle.

A professional survey will include several technical parameters which cannot be expected in a survey carried out by the public. However, it is important that two minimum requirements are met during the measuring: (1) wind speed must be less than $5 \mathrm{~m} / \mathrm{s}$; (2) it must not be raining (Hungarian Decree on Noise measurements 284/2007).

The effect of noise on humans varies according to the wavelength or frequency of the noise. It is common practice to apply a frequency-dependent weighting, the most common weighting used in noise measurement being A-Weighting. We therefore chose a mobile application which outputs $\mathrm{dB}(\mathrm{A})$. It is worth noting that constant noise exposure of around $30 \mathrm{~dB}$ during the night causes sleep disturbance; 30-34 dB hinders communication; 35-54 $\mathrm{dB}$ causes serious annoyance outdoors. Daily exposure for one hour to $55-70 \mathrm{~dB}$ causes hearing impairment, to $70-85 \mathrm{~dB}$ produces hearing impairment, to $85-120 \mathrm{~dB}$ results in hearing impairment of a child, and to levels of around $120 \mathrm{~dB}$ causes hearing impairment for an adult.

The applications use the built-in microphone of a mobile device and are able to measure noise volume in decibels $(\mathrm{dB})$. It is important to note that built-in microphones are optimized for the human voice $(300-3400 \mathrm{~Hz}, 40-60 \mathrm{~dB})$. None of the applications is meant to be used in the place of scientific instrumentation. Depending on the device used, the measurements obtained vary. Devices that use AGC (Automatic Gain Control) will produce significant measurement errors. This is not the fault of the applications.

All measurement points were visited twice if possible: once on a weekday during rush hour, and once at the weekend during off-peak hours. The measurement lasted for a minimum of 5 minutes and the average $\mathrm{dB}(\mathrm{A})$ was recorded in the database. We took care to exclude any sudden volume changes or changes in tone, which might distort the results of the measurements (for example a siren or a wheel grinder.) 
The number of measurement points varied from a minimum of 50 to 350 , according to the municipality or other location. We used free noise-measurement software packages, but mostly Noise Meter, which in previous studies (Pődör \& Révész, 2014 and Murphy \& King, 2016) had proved to be the best for our purposes.

Table 1: Overview of the measurement campaign

\begin{tabular}{|c|c|c|c|}
\hline $\begin{array}{l}\text { Town/place } \\
\text { (Pop. / sq.km) }\end{array}$ & Equipment & Software & Date (rush / off-peak) \\
\hline Ajka $(28,487$ / 95.05) & Nokia Windows Phone & Noise Meter & 15.11.2015 / 21.11.2015 \\
\hline Beled (2,640 / 26.47) & Nokia Lumia 53 & Noise Meter & 20.11.2015 \\
\hline Cserkeszőlő (2,218 / 30.7) & $\begin{array}{c}\text { Samsumg Galaxy Xcover } \\
3\end{array}$ & Noise Meter & 20.11.2015 \\
\hline $\begin{array}{c}\text { Dunaföldvár (8,593 / } \\
111.42)\end{array}$ & Microsoft Lumia 535 & Noisewatch & 17.11.2017 \\
\hline Gyula (30,658 / 255.8) & Huawei P9 Lite & Noise Meter & 29.10.2017 \\
\hline Kapuvár (10,393 / 96.05) & LG G4 & Noise Meter & $\begin{array}{l}\text { 22.10.2016 morning / } \\
\text { 23.10.2016 afternoon }\end{array}$ \\
\hline Nagykanizsa $(48,241$ / 148.4) & Huawei P8 Lite & Noise Meter & 04.11.2106 / 20.11.2016 \\
\hline Nagykőrös (23,694 / 227.94) & LG K8 & Noise Meter & $\mathbf{0 4 . 1 1 . 2 0 1 6 ~ / ~ 0 6 . 1 1 . 2 0 1 6 ~}$ \\
\hline Sopron $(61,780$ / 169.04) & $\begin{array}{c}\text { Samsung J5, J2, } 3 \\
\text { Huawei Y511 }\end{array}$ & Noise Meter & 22.04.2016 \\
\hline $\begin{array}{c}\text { Zalaegerszeg }(58,959 \text { / } \\
102.41)\end{array}$ & Sony Xperia L & Noise Meter & 05.11.2016 / 06.11.2016 \\
\hline $\begin{array}{l}\text { Székesfehérvár (98,673 / } \\
170.89) \text { (part of city only) }\end{array}$ & $\begin{array}{c}\text { Iphone 4S / Sony Xperia } \\
\text { Z3 / LG G2 mini }\end{array}$ & $\begin{array}{l}\text { NoiseTube and } \\
\text { Noise Meter }\end{array}$ & 20.11.2016 \\
\hline Pannonia Ring (0.2) & LG G4 & Noise Meter & 22.10 .2016 \\
\hline $\begin{array}{l}\text { Dolomite mine at } \\
\text { Iszkaszentgyörgy }(0.2)\end{array}$ & $\begin{array}{l}\text { ZTE WayteQ Libra / } \\
\text { Sony Xperia E1 / } \\
\text { VOLTCRAFT SL-200 }\end{array}$ & $\begin{array}{l}\text { Sound meter } \\
\text { and SPL meter }\end{array}$ & 09.04.2015 \\
\hline
\end{tabular}




\section{Results}

We visualized our measurements using graduated symbols and bar charts (see Figures 2 and 3). It should be noted that using the same software on uncalibrated mobile phones resulted in inconsistent measurements, so maps for different municipalities cannot be matched directly to each other.

The first case was a comparative study using 2 mobile phones (ZTE and Sony Xperia E1) and a professional sound-level meter (Voltcraft SL-200), carried out over a relatively small area, a dolomite mine near Iszkaszentgyörgy. The correlations of the measurements between the sound-level meter and the mobile phones were 0.9416 (ZTE) and 0.8722 (Xperia E1). The significance of the correlation was $0.835^{*} 10^{-42}$ (for ZTE) and $4.104 * 10^{-28}$ (for Xperia E1). Although mobile phone measurements cannot replace professional noise maps, the strong and significant correlations suggest that they are suitable for relative measurements, so it is possible to find more and less noisy parts within an area. Figure 1 shows that even the absolute measurement values of the two mobile phones are different from the absolute measurement value of the sound-level meter; they found the same parts of Iszkaszentgyörgy noisy or less noisy.

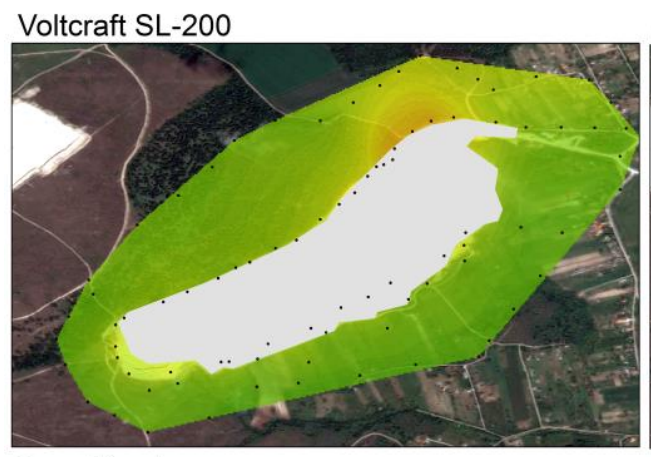

Sony Xperia

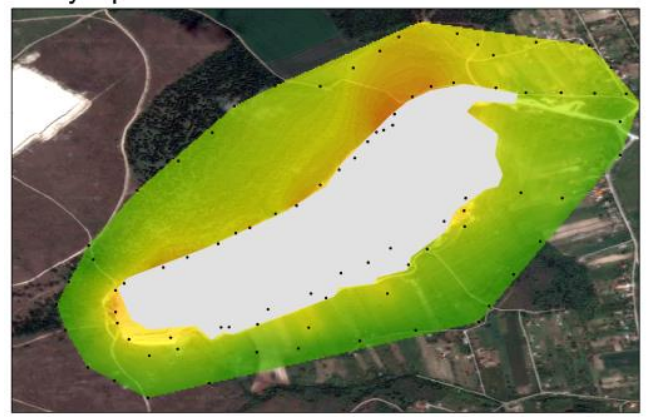

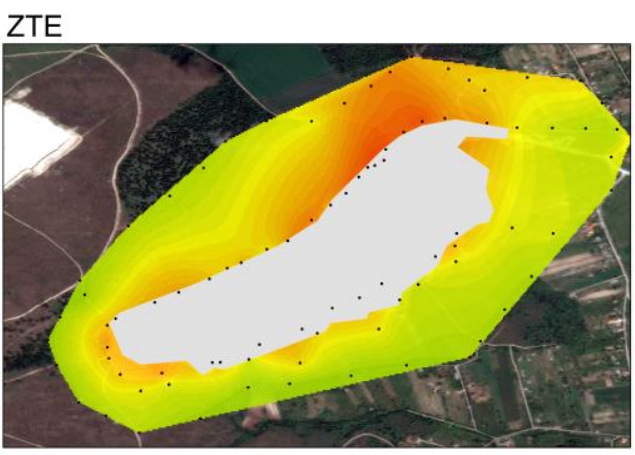

Dolomite mine

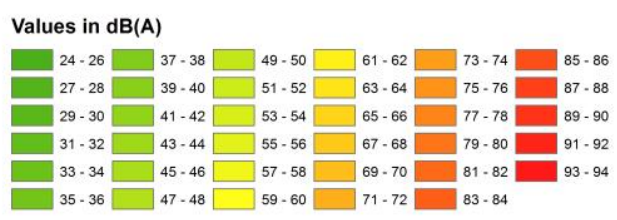

\section{$1: 10,000$}

Figure 1: Maps produced using the measurements of ZTE, Xperia El and Voltcraft SI-200 equipment

In both 2015 and 2016, we made test measurements in the university courtyard and surroundings with a Voltcraft SL-200 sound-level meter and several mobile devices. Table 2 shows that correlations are not in all cases acceptable. We could not carry out all the 
measurements in 2016 due to unfavourable weather conditions (there was a strong wind on the day of the comparative test).

Table 2: Overview of the results of the measurement campaign

\begin{tabular}{|c|c|c|c|}
\hline Location & $\begin{array}{c}\text { equipment correlation } \\
\text { to Voltcraft S1-200 }\end{array}$ & $\begin{array}{c}\text { measurement range } \\
\text { (rush hour) dB(A) }\end{array}$ & $\begin{array}{c}\text { measurement range } \\
\text { (off-peak) dB(A) }\end{array}$ \\
\hline Ajka & 0.53 & $45-90$ & $36-68$ \\
\hline Beled & 0.6 & $32-76$ & $26-64$ \\
\hline Cserkeszólő & 0.6 & $27-66$ & \\
\hline Dunaföldvár & 0.62 & $33-80$ & $33.7-41.6$ \\
\hline Gyula & 0.62 & $42.6-51.2$ & $8.1-45.6$ \\
\hline Kapuvár & no data & $8.2-49.1$ & $26-52$ \\
\hline Nagykanizsa & no data & $32-57$ & $21.9-53$ \\
\hline Nagykőrös & 0.57 & $45.7-63.7$ & $26-73$ \\
\hline Sopron & 0.93 & $25-73$ & $40.4-62.10$ \\
\hline Zalaegerszeg & no data & $41.10-60.20$ & \\
\hline Székesfehérvár & 0.63 & $43.2-66.8$ & $28.1-58.4$ \\
\hline Pannonia Ring & no data & $40.1-62.5$ & \\
\hline
\end{tabular}

Figure 2 presents maps produced from participatory noise measurements. These show areas with higher and lower environmental noise exposure. Visual interpretation supports the hypothesis that mobile phone measurements are capable of indicating that town-centre streets and highways are the noisiest areas in a city, and that railways also generate high environmental noise pollution.

We measured the highest volume near Dunaföldvár, along the M6 motorway. The map of Dunaföldvár demonstrates the importance of constructing motorways at an appropriate distance from housing in order reduce the impact of high noise exposure on citizens. In Sopron, we made several measurements at 344 points. Here we found that not only main roads and railways produce environmental noise; we can also experience high noise levels in the inner city, as the streets are crowded and narrow, so there are no noise absorption possibilities there.

It is also clearly visible that a big shopping centre in Beled (indicated by the letter A on the map in Figure 2), a small, quiet town, has an obvious impact on environmental noise pollution. Our measurements at the dolomite mine (Figure 1) and at the Pannonia Ring racetrack proved to be very informative. In both cases, natural or artificial noise barriers were in place, which definitely reduced environmental noise pollution. We did not, however, have opportunities to measure noise levels during blasting at the mine or during a motor race at Pannonia Ring, which would produce higher levels of noise. 

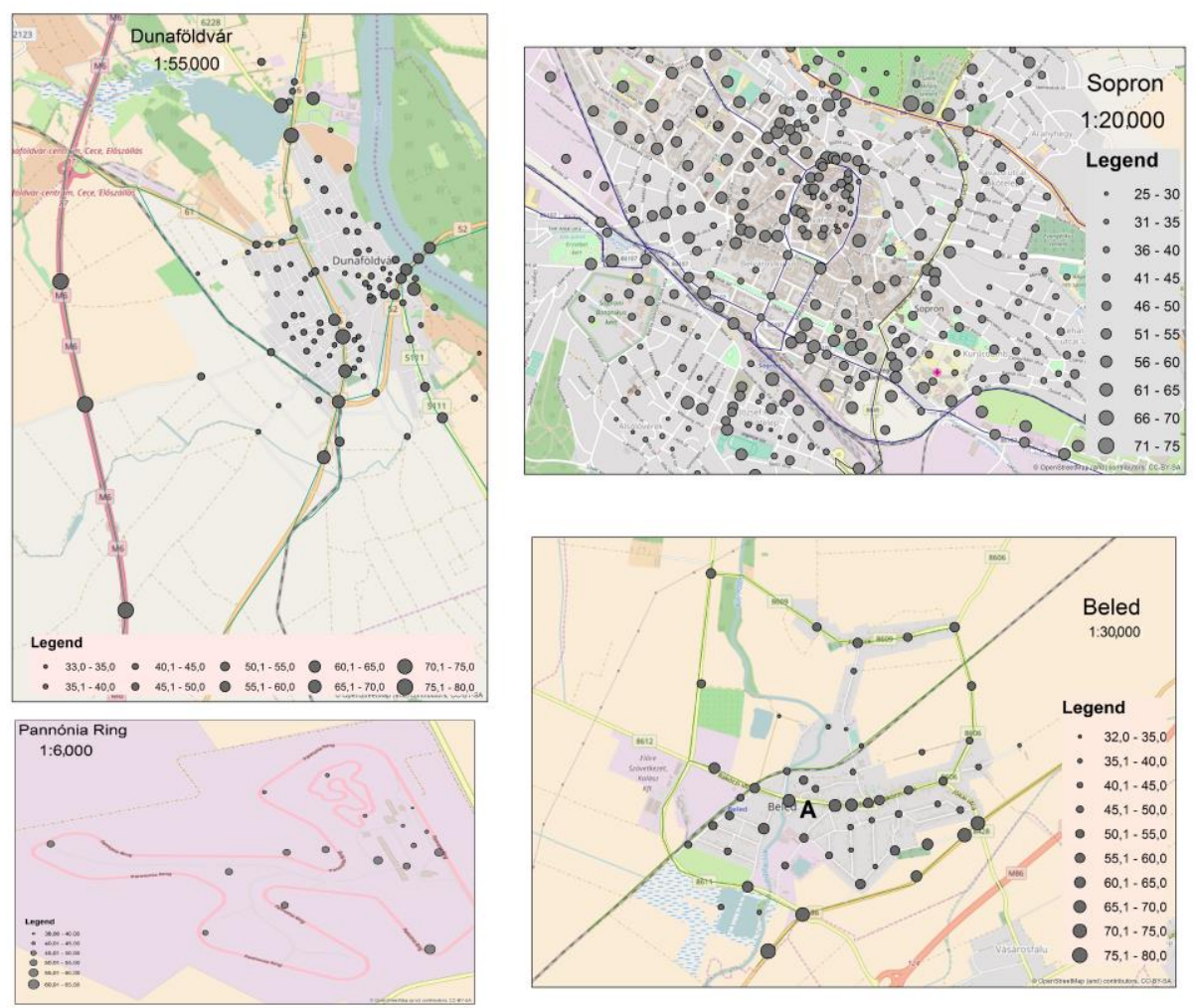

Figure 2: Maps showing $\mathrm{dB}$ levels produced using the measurement results of mobile devices

We also examined whether there was any noticeable variation between measurements taken during rush hour and those taken during off-peak hours (Figure 3). Examining the maps in Figure 3 and data included in Table 2, we can observe slight differences in $\mathrm{dB}(\mathrm{A})$ between rush and off-peak hours. Ajka is the centre of aluminium production; there is also a bauxite mine nearby, as well as various other industries. The maps clearly identify high levels of noise coinciding with periods of heavy traffic, which is characteristic of industrial cities. We could also identify clear differences between rush and off-peak hours in this city. On the other hand, our general experience is that in small towns such as Cserkeszőlő or Kapuvár, there is no great difference between rush and off-peak hours. It is also typical of slightly larger towns such as Nagykanizsa or Zalaegerszeg that the main roads and railways are on the towns' peripheries. Furthermore, the absence of any significant industrial area close to residential areas means that there is no serious noise exposure. In larger towns such as Sopron (Figure 2), we find spatial differences, but the ranges of the decibel levels measured across the city remain very similar. In the case of Sopron, the extent and location of noisy areas are changing. 

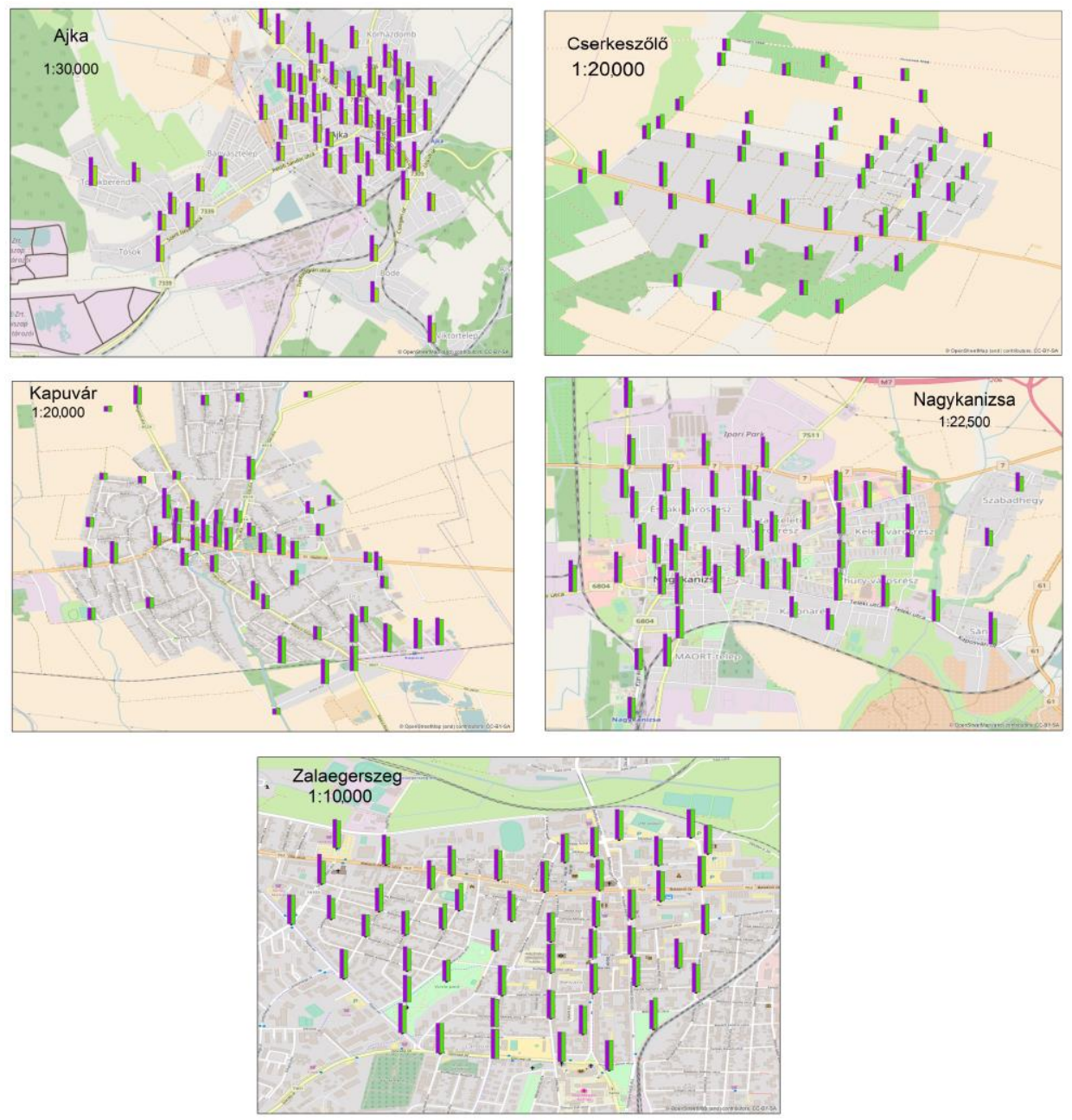

Figure 3: Maps showing rush hours (first column, purple) and off-peak hours (second column, green) produced using the measurements from mobile devices

We also investigated whether distance from the main noise sources (e.g. main roads and railways) has any effect on noise exposure. In Table 3, it is evident in the case of small settlements like Cserkeszőlő and Beled that the negative correlation is significant, which means that the further we are from main roads and railways, the more the noise decreases. 
Table 3: Analyses of the correlation between environmental noise exposure and distance from main roads and railways

\begin{tabular}{|c|c|c|c|}
\hline $\begin{array}{c}\text { Municipality / } \\
\text { place }\end{array}$ & $\begin{array}{c}\mathbf{r} \\
\text { rush hour / off-peak } \\
\text { hours }\end{array}$ & $\begin{array}{c}\text { p values } \\
\text { rush hour / off-peak } \\
\text { hours }\end{array}$ & Nr. of samples \\
\hline Ajka & $-0.1886 /-0.0962$ & $0.1523 / 0.4683$ & 59 \\
\hline Beled & -0.5886 & $1.683 * 10^{-06}$ & 56 \\
\hline Cserkeszőlő & $-0.6399 /-0.6948$ & $4.967 * 10^{-7} / 1.801 * 10^{-8}$ & 50 \\
\hline Dunaföldvár & -0.4496 & $2.632 * 10^{-6}$ & 100 \\
\hline Kapuvár & $-0.3171 /-0.3385$ & $0.02466 / 0.01605$ & 50 \\
\hline Nagykanizsa & $-0.4230 /-0.3158$ & $1.940^{*} 10^{-3} / 0.02377$ & 51 \\
\hline Sopron & $-0.3900 /-0.3526$ & $5.902 * 10^{-14} / 1.631 * 10^{-11}$ & 344 \\
\hline Zalaegerszeg & $-0.5183 /-0.4554$ & $1.099 * 10^{-4} / 8.647 * 10^{-4}$ & 50 \\
\hline
\end{tabular}

\section{Conclusion and Outlook}

In our study using public participants we found that, with some limitations, mobile phones are suitable for making noise measurements. While they are not capable of taking accurate noise measurements, they can be used for differential measurements. A further drawback is that the maps produced using different equipment cannot be compared with each other; they can be analysed on their own only.

In most municipalities and our other locations, the measurements were carried out using several different models of mobile phone, but within one town the same equipment was used for all measurements. We need to carry out further surveys using multiple mobile phones of the same model in order to investigate whether they produce the same outputs when measuring the same noise levels.

The surveys revealed that major roads and railways produce higher noise exposure. These findings could help local authorities in planning infrastructure. Our results confirmed our hypothesis that crowdsourced noise measurements are capable of indicating problematic areas, although they cannot fully replace official noise measurements.

The majority of our measurement points were on main roads, by the railway or at busy road junctions, so there were no surrounding buildings to function as sound barriers. In planning the measurement points for crowdsourced noise maps, it is important to take the presence or absence of buildings by main roads into account.

In the Green Paper on Citizen Science for Europe (2013), the authors emphasize the importance of citizen engagement in environmental policy, stating that 'science-society-policy interactions' can be improved with this type of activity. This theory is also outlined and echoed in Haklay's paper (2012) and in the report on Citizen Science produced for the European Commission DG Environment by the University of the West of England, Bristol 
(2013). We think that a crowdsourced noise measurement campaign is a good example of Citizen Science, as such a campaign could provide evidence for decision makers.

Preliminary measurements made by the public can be a good solution for municipalities which lack financial resources. The results can be followed up by environmental impact assessments, and the towns concerned can commission professionals to make noise maps just of certain areas in order to limit costs. Another positive effect of participatory noise measurement may be that by involving citizens, they feel more responsibility and may participate in further environmental decisions.

\section{References}

Environmental Noise Directive of the European Union 2002/49/EG. Retrieved from: http://ec.europa.eu/environment/noise/directive.htm

Hungarian Government Decree 280/2004. (X.20) Retrieved from: https://net.jogtar.hu/jr/gen/hjegy_doc.cgi?docid=a0400280.kor in Hungarian

Garcia-Martí, I., Torres-Sospedra J., Rodríguez-Pupo L. (2014). A comparative study on VGI and professional noise data. In Huerta, Schade, Granell (Eds). Connecting a Digital Europe through Location and Place. Proceedings of the AGILE'2014 International Conference on Geographic Information Science, Castellón, June, 3-6

Green Paper on Citizen Science (2013). Citizen Science for Europe: Towards a better society of empowered citizens and enhanced research; Science Communication Unit, University of the West of England, Bristol. Report produced for the European Commission DG Environment, December 2013. Retrieved from https://ec.europa.eu/digital-single-market/en/news/greenpaper-citizen-science-europe-towards-society-empowered-citizens-and-enhanced-research

Haklay, M. (2012). Citizen Science and Volunteered Geographic Information - overview and typology of participation. In Sui, D.Z., Elwood, S. \& M.F. Goodchild (Eds.), Crowdsourcing Geographic Knowledge: Volunteered Geographic Information (VGI) in Theory and Practice. Berlin, Springer. 105-122. DOI: 10.1007/978-94-007-4587-2_7

Hungarian Central Statistical Office data about population (2015). Magyarország közigazgatási helynévkönyve. XLS táblázat. Központi Statisztikai Hivatal, Retrieved from http://nepesseg.com

Kanjo, E. (2010). NoiseSpy: A real-time mobile phone platform for urban noise monitoring and mapping. Mobile Networks and Applications, 15(4), 562-574

Karolus J. (2013). Creating noise pollution maps based on user-generated noise measurements. BA dissertation Technische Universitat Darmstadt.

Maisonneuve, N., Stevens, M., Niessen, M. E., \& Steels, L. (2009). Noisetube: Measuring and mapping noise pollution with mobile phones. In Information technologies in environmental engineering, Springer, pp. 215-228

Martí, I., Rodríguez, L., Benedito, M., Trilles, S., Beltrán, A., Díaz, L., \& Huerta, J. (2012). Mobile application for noise pollution monitoring through gamification techniques. Entertainment Computing-ICEC, 562-571

Miller, L., Springthorpe, C., Murphy, E. \& King, E.A., (2016) Environmental Noise Mapping with Smartphone Applications: A participatory noise map of West Hartford, CT. In INTER-NOISE and NOISE-CON Congress and Conference Proceedings Institute of Noise Control Engineering, 252(2), pp. 445-451

Murphy, E., \& King, E. A. (2016). Testing the accuracy of smartphones and sound level meter applications for measuring environmental noise. Applied Acoustics, 106, 16-22 
Pődör A., \& Révész. A. (2014). Noise map: professional versus crowdsourced data. In Huerta, J., Schade S., Granell C. (Eds.), Proceedings of the 17th AGILE International Conference on Geographic Information Science, Castellón, Spain

Pődör, A. Shokirov S., Abdurahmanov I., Narieva A., \& Ormanova G.(2015). Creating a noise pollution map of Sopron city. In Boda J. (Ed.), Az elmélet és a gyakorlat találkozása a térinformatikában: Térinfomatikai Konferencia és Szakkiállítás. Debrecen. Debreceni Egyetemi Kiadó, pp. 347-354 (in Hungarian)

Rana, R. K., Chou, C. T., Kanhere, S. S., Bulusu, N., \& Hu, W. (2010). Ear-phone: an end-to-end participatory urban noise mapping system. In Proceedings of the 9th ACM/IEEE International Conference on Information Processing in Sensor Networks. ACM, pp. 105-116

Santini S, Ostermaier B., Adelmann R., (2009). On the Use of Sensor Nodes and Mobile Phones for the Assessment of Noise Pollution Levels in Urban Environments, Sixth International Conference on Networked Sensing Systems (17-19 June 2009, Pittsburgh, PA, USA), IEEE, 31-38 